\title{
Herpes simplex virus type 1: an atypical presentation of primary infection
}

\author{
Inês Medeiros, ${ }^{1}$ Cristiana Maximiano, ${ }^{1}$ Teresa Pereira, ${ }^{2}$ Maria Miguel Gomes ${ }^{1}$
}

'Paediatrics Department, Hospital de Braga, Braga, Portugal

${ }^{2}$ Dermatology Department, Hospital de Braga, Portugal

\section{Correspondence to}

Dr Inês Medeiros,

inesdemedeiros@hotmail.com

Accepted 11 April 2018

\section{DESCRIPTION}

A 3-year-old female child with personal history of atopic dermatitis presented with confluent vesicular and shallow ulcers pruritic rash surrounded by an erythematous base located to both hands and wrists, with 1-week evolution. She had no fever or other symptoms. There was no personal or family history of herpetic infections. Topical antibiotic, topical corticosteroid and oral antihistaminic were tried with no improvement. Physical examination was unremarkable except for generalised dry skin and lesions in figure 1. On suspicion of superinfected viral rash or bullous impetigo she was treated with oral amoxicillin and clavulanic acid (concentration of $250 \mathrm{mg} / 62.5 \mathrm{mg}$ with the dose of $50 \mathrm{mg} / \mathrm{kg} /$ day) and topical fusidic acid. One week later, at re-evaluation, there was progression of the rash (figure 2) and the mother reported herpes labialis on the father. At this time, the diagnosis of primary eczema herpetic infection was also considered. Oral acyclovir $(20 \mathrm{mg} / \mathrm{kg}$ every 6 hours for 5 days) and cefuroxime $(30 \mathrm{mg} / \mathrm{kg}$ every 12 hours for 7 days) were started, with complete resolution of the lesions after 10 days. PCR assay of lesion's swab was positive for herpes simplex virus (HSV) type 1 and bacterial culture was negative.

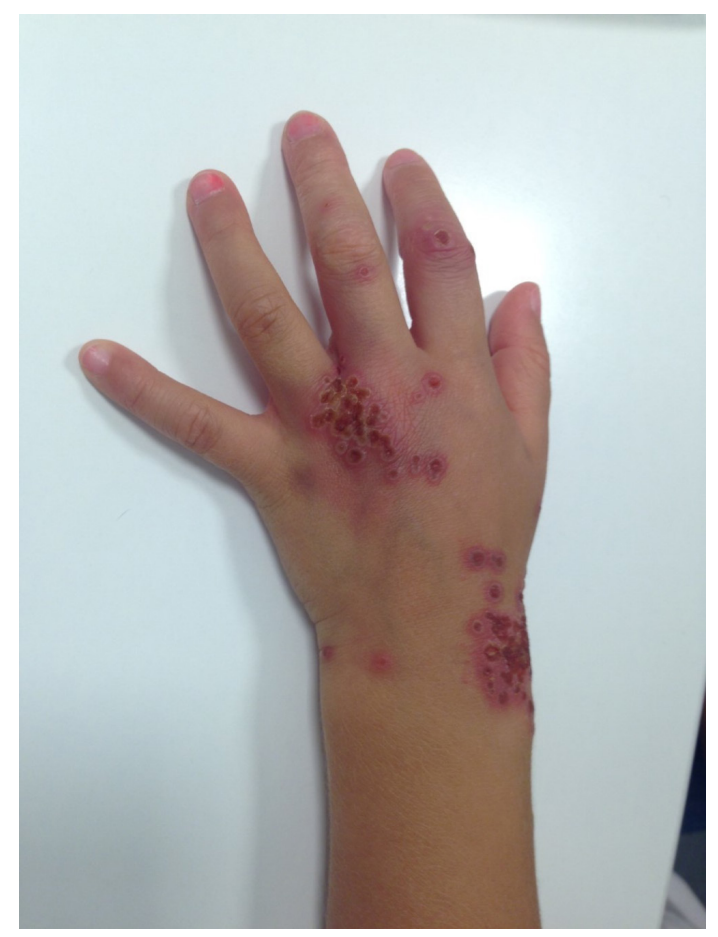

Figure 1 Grape-like clustered shallow ulcers in the dorsal surface of the left hand.

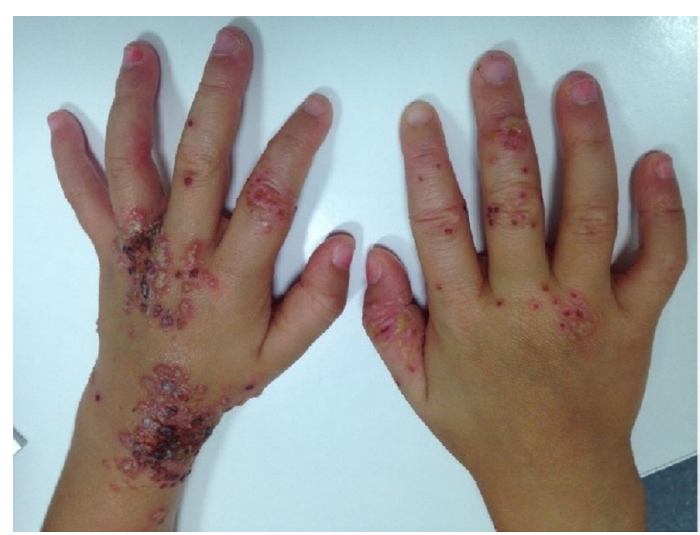

Figure 2 Confluent vesicles and shallow ulcers with bilateral localisation in both hands, grouped in the left hand and disseminated in the right hand.

HSVs cause a variety of illnesses, depending on the anatomic site where the infection is initiated, the immune state of the host and whether the symptoms reflect primary or recurrent infection. Common infections involve the skin, eye, oral cavity and genital tract. Infections tend to be unilateral, mild and self-limiting, except in the immunocompromised patient and newborns. 12

The authors want to emphasise the fact that the primary HSV infection can present in atypical forms, in which the lesions may be generalised, symptomatic, severe and with bilateral involvement. Therefore, this diagnosis should be considered in the differential diagnosis of other vesiculobullous diseases ${ }^{3}$.

\section{Learning points}

Acute herpetic gingivostomatitis is the most common clinical presentation of herpes simplex virus (HSV) primary infection in children aged 6 months to 5 years.

- Eczema herpeticum is a rapid dissemination of an HSV infection over the eczematous atopic skin, prone to superinfection with Staphylococcus aureus or Streptococcus pyogenes.

- HSV PCR assay is the most sensitive method to confirm HSV infection.

Contributors IM collected the data, wrote the manuscript and reviewed the literature. CM collected the data and reviewed the literature. TP and MMG did the critical review of the manuscript.

Funding The authors have not declared a specific grant for this research from any funding agency in the public, commercial or not-for-profit sectors. 


\section{Images in...}

Competing interests None declared

Patient consent Parental/guardian consent obtained.

Provenance and peer review Not commissioned; externally peer reviewed.

(c) BMJ Publishing Group Ltd (unless otherwise stated in the text of the article) 2018. All rights reserved. No commercial use is permitted unless otherwise expressly granted.

\section{REFERENCES}

1 Stanberry LR. Herpes Simplex Virus. In: Kliegman Robert M, Stanton Bonita F, Joseph G, Schor Nina F, eds. Nelson Textbook of Pediatrics. 20th edn. USA: Elsevier, 2016:1572-9.

2 James SH, Whitley RJ. Treatment of herpes simplex virus infections in pediatric patients: current status and future needs. Clin Pharmacol Ther 2010;88:720-4.

3 Bolognia J, Jorizzo J, Schaffer J. Dermatology. 3rd edn. London: Elsevier.

Copyright 2018 BMJ Publishing Group. All rights reserved. For permission to reuse any of this content visit http://group.bmj.com/group/rights-licensing/permissions.

BMJ Case Report Fellows may re-use this article for personal use and teaching without any further permission.

Become a Fellow of BMJ Case Reports today and you can:

- Submit as many cases as you like

- Enjoy fast sympathetic peer review and rapid publication of accepted articles

- Access all the published articles

Re-use any of the published material for personal use and teaching without further permission

For information on Institutional Fellowships contact consortiasales@bmjgroup.com

Visit casereports.bmj.com for more articles like this and to become a Fellow 